\title{
A formação da previdência no contexto da seguridade social: uma análise da policy agenda-setting
}

\author{
Raquel ANDRAde Silva de Oliveira ${ }^{1}$ \\ BRUNO TAVARES ${ }^{2}$ \\ THIAGO de MElo TEIXEIRA DA COSTA ${ }^{3}$ \\ SUELY de FÁtIMA RAMOS SILVEIRA ${ }^{1}$ \\ 1 Universidade Federal de Viçosa (UFV) / Programa de Pós-Graduação em AdMinistração, Viçosa - MG, BRASIL \\ 2 Universidade Federal de VIçOSA (UFV) / DePARTAMENTO de AdMINISTRAÇÃo, VIÇOSA - MG, BRASIL \\ ${ }^{3}$ Universidade Federal de VIçosa (UFV) / Departamento de AdMINISTRAÇÃo E CONTABILIdAde, ViçOSA - MG, BRASIL
}

\begin{abstract}
Resumo
Este trabalho está inserido no contexto da atual agenda de reformas que envolve a Previdência Social no Brasil. O objetivo geral visou compreender, por meio da Teoria dos Múltiplos Fluxos, de John Kingdon (1984, 2003), como a Previdência tornou-se um elemento da Seguridade no âmbito das políticas públicas na Constituição Federal de 1988 (CF/88). Em termos metodológicos, a pesquisa é predominantemente documental e bibliográfica, com abordagem qualitativa e utilização da técnica de análise de conteúdo categorial de grade fechada. A análise dos fluxos (problemas, soluções, política) com a inserção da influência internacional como um fluxo analítico indicou que a Previdência Social enquanto um problema público da década de 1980 estava atrelada a fatores econômicos e de gestão. Quando esse problema tocou a agenda pública, distintas alternativas foram formuladas, incluindo a ideia de expansão da cobertura social por meio da criação da Seguridade Social.
\end{abstract}

Palavras-chave: Previdência social. Seguridade social. Agenda pública.

\section{The Brazilian pension system in the context of social security: an analysis of policy agenda-setting}

\begin{abstract}
This study considers the current agenda of reforms in the Brazilian pension system and aims to understand how the pension system became an element of social security in the 1988 Brazilian Federal Constitution. The methodology is qualitative, predominantly documentary and bibliographical. The research uses content analysis, determining the coding categories before the data analysis, based on John Kingdon's $(1984,2003)$ multiple stream framework (problems, policies, and politics), including the. category "international influence." The study showed that the pension system was a public problem tied to economic and management factors in the 1980s. When the problem entered the public agenda, different policies were formulated, including expanding social welfare through creating a social security system.
\end{abstract}

Keywords: Brazilian pension system. Social security. Policy agenda-setting.

La formación de la previsión social en el contexto de la seguridad social: un análisis de la configuración de la agenda de politicas

\section{Resumen}

Este trabajo se inserta en el contexto de la agenda actual de reformas que involucra la previsión social en Brasil. El objetivo general era comprender cómo la previsión se convirtió en un elemento de la seguridad en el ámbito de las políticas públicas de la Constitución Federal de 1988, a través de la teoría de múltiples corrientes de John Kingdon (1984, 2003). En términos metodológicos, la investigación es predominantemente documental y bibliográfica, con un enfoque cualitativo, se utilizó la técnica de análisis de contenido categórico de rejilla cerrada. El análisis de los flujos (problemas, soluciones, política) con la inserción de influencia internacional indicó que la previsión social como un problema público de la década de 1980 estaba vinculada a factores económicos y de gestión. Cuando este problema llegó a la agenda pública, se formularon diferentes alternativas, incluida la idea de ampliar la cobertura social a través de la creación de la seguridad social.

Palabras clave: Previsión social. Seguridad social. Agenda pública. 


\section{INTRODUÇÃO}

A Previdência, em diferentes governos, foi apresentada dentro de uma agenda de reformas no Congresso Nacional. Importa, pois, compreender os sentidos e a trajetória desta temática como um problema público. $O$ estudo apresentado neste artigo pode auxiliar no entendimento da complexidade da política pública de Previdência destacando a formação da agenda pública da década de 1980, que culminou com a criação da Seguridade Social na Constituição Federal de 1988 (CF/88).

As teorias e os estudos sobre análises de políticas públicas (policy analisys) advêm de diferentes campos do conhecimento, tais como: ciência política, ciências sociais, sociologia, economia, administração pública e, também, direito. Abordar a Previdência Social como política pública exige expor os condicionantes e conceitos próprios desta perspectiva. Assume-se, portanto, a necessidade de analisá-la como problema público, relativo ao acordo social sobre os direitos relativos à cidadania e não restritos a aspectos pontuais, como o gerenciamento de organizações públicas.

Dentro do campo das políticas públicas, os estudos sobre problema e agenda são destinados à compreensão de como o conjunto de assuntos desperta a atenção dos formuladores de políticas públicas e passa a ser prioridade na agenda governamental. Autores como Cobb e Elder (1972), John Kingdon $(1984,2003)$ e Baumgartner e Jones (1993) são referência nesses temas e apresentam conceitos fundamentais na compreensão da policy agenda-setting. Kingdon $(1984,2003)$ demarca categorias significativas no estudo de agenda de políticas públicas, incluindo problemas, alternativas e a dinâmica do processo político. Esses três componentes são como fluxos, condicionalmente vinculados por seu processo, carregando conteúdo complexo e variável, mas operando independentemente um do outro.

De acordo com o exposto, a Seguridade Social é essencialmente uma política de inclusão, por reconhecer o direito dos cidadãos à proteção social com base em outros critérios universalizáveis que não apenas o da capacidade de contribuição individual daqueles que estão formalmente vinculados ao mercado de trabalho. Assim, a Previdência foi preconizada como direito social pela $\mathrm{CF} / 88$ e reformada desde então sob a perspectiva financeira, mas cumpre destacar que ela se relaciona com a concepção de cidadania e dignidade humana.

No escopo desta pesquisa, pretende-se responder ao seguinte problema de pesquisa: como se deu a formação da agenda pública que levou a CF/88 a abranger as políticas de Previdência Social no campo da Seguridade Social?

O objetivo geral desse trabalho é compreender, por meio da Teoria dos Múltiplos Fluxos, de Kingdon (1984, 2003), como a Previdência Social torna-se um elemento da Seguridade no âmbito das políticas públicas na CF/88.

Para tal, foi necessário adaptar o modelo de Múltiplos Fluxos, de Kingdon $(1984,2003)$, à realidade da política pública brasileira, tendo como resultado um modelo analítico apropriado ao estudo da Previdência Social que permita compreender a evolução desta temática na década de 1980 passando pelos fluxos dos problemas, soluções e política, bem como identificar os empreendedores da política, caracterizando a Assembleia Nacional Constituinte (ANC) de 1987 como uma janela de oportunidades. Portanto o desafio teórico proposto por este trabalho é a interpretação da policy agenda-setting sob a lente teórica do modelo de Múltiplos Fluxos adaptado à realidade da política nacional brasileira, sobretudo no que diz respeito à influência internacional na formação da agenda da década de 1980. Como resultado, espera-se trazer uma contribuição teórica e empírica sobre a formação da Seguridade Social no Brasil.

O trabalho é fruto de uma pesquisa teórica e empírica, de abordagem qualitativa, predominantemente documental e bibliográfica. A coleta dos dados foi realizada no site institucional do Congresso Nacional; a pesquisa bibliográfica foi realizada por meio da revisão de literatura, utilizando-se a técnica de análise de conteúdo categorial de grade fechada. Foram analisadas as atas das reuniões que deliberaram sobre o futuro das políticas de previdência social do Grupo de Trabalho para a Reestruturação da Previdência Social (GRPS); atas das audiências públicas que deliberaram sobre Previdência Social na Subcomissão da Saúde, Seguridade e Meio Ambiente/Comissão da Ordem Social da Assembleia Nacional Constituinte de 1987.

Este trabalho é composto pela presente introdução, por referencial teórico, no qual se expõem os aspectos históricos e teóricos da formação da agenda de políticas públicas, para então introduzir a temática sobre os modelos de análise de agenda, em especial o modelo de Múltiplos Fluxos, de Kingdon. A trajetória da Previdência Social brasileira é abordada de forma descritiva para ilustrar os principais momentos dessa política pública. Em seguida são apresentados os delineamentos metodológicos e depois os resultados e discussões. 


\section{REFERENCIAL TEÓRICO}

Para a reflexão teórica do artigo, apresenta-se nesta seção a gênese da abordagem dos Múltiplos Fluxos. Encontrada nas obras de Kingdon, de 1984 e 2003, foi, ainda, refinada com os textos e críticas de Baumgartner e Jones (1993), Sabatier (1999, 2007), Sabatier e Weible (2014) e Zahariadis (1999, 2007, 2014). É verdade que autores nacionais como Capella (2007), Rua (2009), Secchi (2014), Souza (2006) e outros enriqueceram o entendimento do modelo de Múltiplos Fluxos. Desejando avançar neste debate, argumenta-se a favor da utilização e adaptação do modelo de Múltiplos Fluxos no Brasil, tendo em vista as diferentes configurações do sistema político e dos modelos jurídicos adotados.

\section{O modelo de Múltiplos Fluxos, de Kingdon: evolução, características, adaptações e críticas}

Nas décadas de 80 e 90, os estudos sobre policy agenda-setting foram intensificados com as pesquisas de Kingdon (2003) e Baumgartner e Jones (1993), que exploraram de forma empírica as teorias que tais estudos desenvolveram sobre a formação das diferentes agendas.

Kingdon (2003) analisa a agenda-setting por meio do modelo de Múltiplos Fluxos. Ele considera que as políticas públicas podem ser entendidas de acordo com um processo que abarca quatro etapas: o estabelecimento da agenda, as alternativas para a formulação da política, a escolha dessa alternativa e a implementação desta.

O modelo dos Múltiplos Fluxos foi elaborado por Kingdon (2003) com base no modelo garbage can, de Cohen, March e Olsen (1972). O modelo de Múltiplos Fluxos foi desenvolvido a princípio para analisar políticas públicas na área da saúde e transportes do governo norte-americano. Posteriormente, o modelo de Kingdon tornou-se referência nos estudos sobre formulação de políticas governamentais, sendo utilizado para explicar por que determinadas questões despertam o interesse passando a integrar a agenda de políticas governamentais e algumas outras soluções referentes aos problemas ganham relevância. Este modelo teórico é adequado ao estudo da inserção da Seguridade na CF/88, pois representa uma ruptura com a conformação anterior, exigindo a necessidade de esclarecer os condicionantes para tal acontecimento, isto é, pelos conceitos analíticos propostos no modelo: os fluxos que conformaram a seguridade como política pública a partir de então.

Em Kingdon (2003), a agenda de políticas constitui-se um processo com três etapas ou fluxos, na primeira delas (problem stream) identificam-se os problemas e tenta-se diferenciá-los das questões. Os problemas, para ele, são construções sociais de tal forma relevantes que passam a fazer parte da agenda. As questões não são necessariamente problemas que devem ser inseridos na agenda, ou seja, há problemas mais complexos comparativamente a outros.

Determinados problemas detêm mais atenção dos políticos, em detrimento de outros. Tal fato se explica pela forma como os atores tomam conhecimento dessas situações e, também, pela maneira como as autoridades reconhecem as questões públicas e passam a tratá-las com prioridade (Kingdon, 2003).

As diferentes maneiras como as autoridades reconhecem os problemas são: a) indicadores, que podem tanto apontar determinada situação problemática quanto a sua magnitude; b) evento-foco, como um desastre ou uma crise, que chama a atenção para algumas situações mais do que para outras - neste caso, é preciso que tal evento esteja acompanhado de indicação mais precisa, para que não receba atenção passageira -; e c) feedback de programas existentes, seja formal, como avaliação, ou informal, como reclamações que chegam até os governos (Kingdon, 2003).

O segundo fluxo (policy stream) compreende o conjunto de possíveis soluções. Nesse processo há a seleção de ideias que são viáveis ao contexto da política pública. Mesmo nem sempre consensual, essa seleção eleva as ideias às propostas que terão mais robustez nas próximas etapas.

O fluxo das alternativas, como é conhecido, também chamado de "sopa de ideias", trata-se da etapa na qual, após o reconhecimento do problema público, os diferentes atores visíveis e invisíveis vão propor medidas para enfrentar o problema. Essas alternativas ou soluções ocorrem muitas vezes em um processo de combinação, ou exclusão, no qual várias possibilidades surgem, mas só algumas ganharão prioridade no plano político (Rua, 2009).

As propostas, via de regra, são propagadas por pesquisadores, consultores, assessores e burocratas que tenham reconhecimento na comunidade política. Os meios de seleção entre as alternativas possíveis no mundo político envolvem os estudos de viabilidade técnica; a possível congruência com os valores dos membros da comunidade de especialistas da área; aceitabilidade do público; receptividade dos políticos e outros (Capella, 2007; Rua, 2009). 
Portanto as alternativas, depois de discutidas, passam por um processo de difusão para que sejam reconhecidas e aceitas tanto pela sociedade quanto pelo corpo político. De acordo com grande parte da literatura, esse fluxo representa a dinâmica das políticas públicas.

A última etapa que abarca a dimensão política (political stream) possui suas próprias dimensões e regras, independente das anteriores, uma vez que diz respeito a influências do humor nacional, fluxo político e das mudanças internas do governo. Quando estes últimos elementos reúnem-se, podem gerar uma oportunidade de mudança de agenda (Capella, 2007).

Para Kingdon (2003), a janela de oportunidades (policy window) ocorre quando um problema é reconhecido, uma solução é apresentada e a política é propícia à sua abordagem por meio da sua entrada na agenda. Portando a mudança da agenda é possível quando há a reunião dos três fluxos, mas convém destacar que a abertura da agenda é tanto provisória quanto transitória. Considera-se o momento em que a janela está aberta uma circunstância primordial, a qual é identificada pelos empreendedores da política (policy entrepreneurs).

De acordo com o modelo teórico, a janela de oportunidades originada do Modelo de Múltiplos Fluxos, de Kingdon (2003), possui diferentes interpretações. Wu, Ramesh, Howlett e Fritzen (2014) fazem analogia às janelas de oportunidades problematizando as circunstâncias em que elas ocorrem. Segundo esses autores existem quatro tipos de janela: rotineira, discricionária, aleatória e induzida. A rotineira ocorre como os ciclos de orçamento, que já são esperados; a discricionária varia de acordo com o comportamento dos políticos; as aleatórias não são esperadas e de fato surpreendem os gestores; já as induzidas são propositalmente criadas para o fim de mudanças na política.

Seguindo esse entendimento, alguns atores têm o papel relevante no processo de definição da agenda e na formulação de políticas públicas. Há ainda os atores visíveis: o presidente da República (o principal deles), burocratas, parlamentares, ministros, partidos políticos, grupos de interesse e a mídia. Existem também os atores invisíveis, como os servidores públicos, acadêmicos, pesquisadores e consultores. Em suma, os visíveis são mais influentes e os invisíveis têm atuação na agenda de decisão por meio da escolha das alternativas (Capella, 2007).

Figura 1

Modelo dos múltiplos fluxos

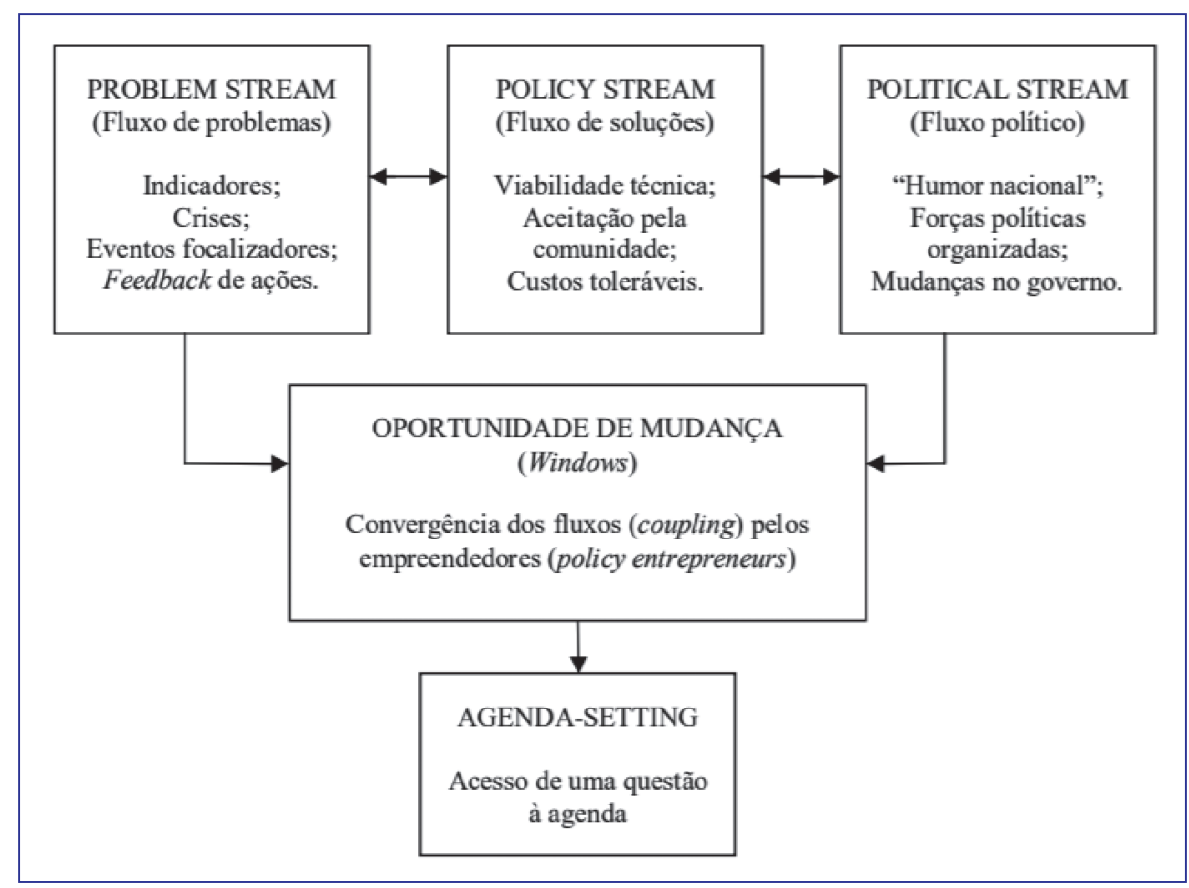

Fonte: Capella (2007, p. 32). 
A análise crítica ao modelo dos Múltiplos Fluxos diz respeito à apreciação de Zahariadis (2007) sobre a estrutura e abstração do modelo, especialmente em relação à sua lógica contingencial. Nesse sentido, Zahariadis (2007) faz a análise desse modelo consoante as políticas públicas de outros países, além de aprofundar o exame da política pública até a etapa da formulação, principalmente focando na questão da privatização. Para esse autor, Kingdon (2003) cria um modelo uniforme em uma realidade em que a ambiguidade é muito intensa, principalmente pelo fato de que os legisladores e burocratas têm uma alta rotatividade, o que comprometeria a análise empírica da política.

Além desses aspectos, Zahariadis (2007) questiona a conduta dos formuladores da política. Enquanto para Kingdon (2003) os formuladores previamente já sabem o que querem e quais decisões vão tomar, para o primeiro autor os anseios e as vontades dos formuladores mudam a todo instante, o que torna ainda mais complexa a análise por meio dos Múltiplos Fluxos.

Contudo, Weick (2001), em oposição à Zahariadis (2007), relata que o modelo dos Múltiplos Fluxos cria uma maneira eficiente de explicar como os sistemas políticos e as organizações dão sentido a um mundo predominantemente ambíguo. Ou seja, a real contribuição de Kingdon (2003) para a policy analisys é exatamente conseguir criar lentes teóricas e ferramentas empíricas que permitam compreender essa realidade complexa e confusa.

Jones et al. (2016) fazem uma meta-análise dos estudos científicos no lapso temporal de 2000 a 2013 que utilizaram o modelo de Múltiplos Fluxos, a fim de elucidar a consistência e coerência do uso dos conceitos criados por Kingdon pelos pesquisadores do mundo todo.

Jones et al. (2016) constataram que em 65 países já se fez uso dessa teoria, a maioria das pesquisas contemporâneas é oriunda dos Estados Unidos da América (EUA) e da União Europeia. Diversas pesquisas estão distribuídas em estudos de nível municipal, estadual, federal e internacional. Analisando todas as obras, constatou-se que os autores aplicaram predominantemente a metodologia qualitativa, e alguns conceitos, por necessidade acadêmica, foram adatptados ao longo do tempo, para captar as diferentes nuances das pesquisas. Portanto os conceitos oriundos do modelo foram sendo aperfeiçoados de acordo com a realidade das pesquisas.

Quatro grandes divisões observadas no bojo dessas pesquisas ajudam a compreender as adaptações do modelo ao caso concreto: aquelas que são fiéis aos conceitos de Kingdon (2003) e agregam outros autores da área; as que usam os fluxos como conceitos abstratos e não operacionalizaram a pesquisa de forma procedimental; estudos de caso qualitativos que foram regidos por essa teoria; e, por fim, adaptações à teoria que ocorreram com o passar do tempo e lançaram novos conceitos ainda inacabados.

O presente trabalho enquadra-se na vertente dos trabalhos que adaptara a teoria propondo a inserção da análise do ambiente internacional, sem necessariamente estar aliado a algum dos fluxos, considerando a ideia de que o modelo de Múltiplos Fluxos está aberto a adaptações. A inserção do fluxo internacional justifica-se pela potencial similaridade de desafios que governos e sociedades enfrentam, manifestada por pressão internacional de organismos mundiais, incentivando ou legitimando demandas de grupos de interesses locais. Embora estudos como os Oliveira (2008) e Pelarez, Invernizzi, Fuck, Bagatolli e Oliveira (2017) considerem o ambiente internacional na análise da política nacional - o primeiro, especificamente, a política ambiental, de ciência e tecnologia; o segundo, a política de educação financeira -, este aspecto é ausente no modelo e relevante para compreender a agenda especialmente em países periféricos.

Diante do exposto até aqui, a escolha pelo modelo de Múltiplos Fluxos, de Kingdon, dá-se em virtude de esse modelo possuir um arcabouço teórico e metodológico capaz de elucidar como ocorreu a formação da Previdência Social no contexto da Seguridade Social de 1988, ressaltando-se que foram feitas algumas adaptações ao modelo para aproximá-lo à realidade das políticas públicas brasileiras.

\section{A trajetória das políticas públicas de Previdência Social no Brasil}

A formação da Seguridade Social brasileira na qual está inserida a Previdência Social pode ser dividida em cinco momentos distintos. De 1923 a 1930: promulgação da Lei Eloy Chaves e criação das Caixas de Aposentadorias e Pensões (CAPs); de 1931 a 1945: aperfeiçoamento das CAPs e criação dos Institutos de Aposentadorias e Pensões (IAPs); de 1946 a 1963: período de redemocratização do país, fim do modelo de capitalização e início do modelo de repartição; de 1964 a 1987: autoritarismo, reestruturação conservadora e criação do Instituto Nacional de Previdência Social (INPS) e do Fundo de Assistência do trabalhador Rural (Funrural); de 1988 a 2017: promulgação da Constituição Federal de 1988 e consequente implantação do Estado democrático de direito e das reformas previdenciárias contemporâneas (Silva, 2014). 
O surgimento da Previdência Social como política social institucionalizada ocorre em um momento histórico de acirramento das lutas e conflitos entre diferentes forças sociais. Por um lado, a Previdência se apresenta como importante conquista, por intermédio da legislação social (Lei Eloy Chaves, 1923), uma vez que é capaz de cobrir, reduzir ou prevenir os riscos e vulnerabilidades sociais. Contudo, por outra via, a institucionalização da Previdência Social foi um eficaz mecanismo cunhado pelo Estado e pela classe patronal para promover a desestabilização do movimento sindical ao somente incluir no sistema de proteção social a classe trabalhadora formal - os trabalhadores urbanos com carteira assinada. Logo, quando se analisam os motivos de formação da Previdência Social, verifica-se que se trata de uma medida estatal-patronal de cooptação de classes, excludente e manipuladora dos movimentos organizados dos trabalhadores (Boschetti, 2009; Vianna, 1998).

Após a promulgação da Lei Eloy Chaves (Decreto $n^{\circ} 4.682 / 1923$ ), que contemplava planos de aposentadoria e outros benefícios para a classe trabalhadora dos ferroviários (CAP), a Previdência Social tornou-se uma tendência nacional e em pouco tempo proliferou-se pelo país. Em três anos foram criadas 183 CAPs, posteriormente aperfeiçoadas, dando origem aos IAPs. De um lado, as CAPs tinham a intervenção estatal; de outro, os IAPs eram categorias independentes do Estado, consistindo em uma mobilização de empregados e empregadores (Zanirato, 2003).

Outro momento de relevância para a Previdência Social (1931 a 1945) foi o contexto da Era Vargas, quando, após a Revolução de 30, intensificaram-se as políticas de educação, saúde, previdência, habitação e trabalho. Para alguns autores, são consideradas políticas de "cidadania regulada", uma vez que o seu ápice encontra-se no período não democrático do governo Vargas. A promulgação da Consolidação das Leis Trabalhistas (CLT) ocorreu em 1943 e, desde então, o trabalho formal passou a ser tratado de forma paralela à evolução das leis previdenciárias, uma vez que a Previdência criava um ambiente propício à regulação do trabalho, e, ainda, como fonte de receitas e demanda da classe trabalhadora (Silva, 2014).

Por ocasião da Nova República (1945 a 1964), o país passou por diferentes chefes de Estado, como Juscelino Kubitschek, Jânio Quadros e João Goulart, até um novo período de autoritarismo com a ditadura civil-militar. Nesse lapso temporal, ocorreram mudanças no campo previdenciário, como a promulgação da Lei Orgânica da Previdência Social (LOPS) (Lei no 3.807/1960) e a aprovação do Regimento único das IAPs em 1963 (Lanzara, 2016; Zanirato, 2003).

No período da ditadura civil-militar (1964 a 1985), a Previdência já estava se tornando mais robusta, com mais contribuintes e arrecadações. Passou a ser vista como uma fonte de riqueza para o custeio do desenvolvimento do país naquela época, configurando-se em um pacto entre o Estado e a burocracia. O aumento na concessão de benefícios consistiu em uma política social tática para legitimar o governo militar daquela época. Um grande acontecimento em 1966 foi a unificação dos benefícios do seguro social por meio do INPS (Lanzara, 2016; Silva, 2014).

Assim, o regime empreendeu um acréscimo aos direitos sociais pautado no universalismo precário, em detrimento dos direitos políticos, para sustentar a legitimidade do governo ditatorial perante o povo, embora ainda se constituindo em um Estado segmentado e incapaz de articular os inúmeros interesses emergentes (Vianna, 1998).

O contexto da redemocratização (1985 a 1988) foi de grande valia para a Seguridade Social, uma vez que na elaboração da $\mathrm{CF} / 88$ priorizou-se a cidadania por meio da universalização do acesso às várias políticas públicas de previdência. A CF/88 é, assim, um marco jurídico legal para a proteção de direitos sociais, dentre eles a Previdência Social. Nesse sentido, as políticas de proteção social que contemplam a Seguridade Social visam resguardar a Saúde, a Assistência Social e a Previdência Social. A Seguridade Social surgiu com esse tripé (Saúde, Assistência e Previdência) após a CF/88, cujo caráter protetor tentou assegurar o máximo de direitos possíveis ao cidadão (Baptista, 1998).

Vale destacar que a Seguridade Social seria responsável por proteger o indivíduo e a família contra as adversidades da vida, já a Previdência Social, como parte integrante da Seguridade no contexto do Estado de bem-estar social, seria responsável por amparar o trabalhador das desventuras que poderiam afastá-lo do mercado de trabalho (Costa, 2009).

As políticas de proteção social foram intensificadas com a promulgação da CF/88 por meio da criação de princípios e diretrizes que direcionam as políticas ao bem-estar social, à equidade, solidariedade e dignidade humana. Dessa forma, a CF/88 enquadrou o direito à Seguridade Social como direito fundamental que tem como objetivo contribuir para eliminar a pobreza e reduzir as desigualdades sociais (Lobato, 2016).

Em oposição ao contexto de 1988, com o auge da proteção dos direitos sociais por meio da promulgação da "Constituição Cidadã", a década de 1990 iniciou uma verdadeira onda de reformas, principalmente com as Emendas Constitucionais no 20, 41 e 47 sob os auspícios de conter o déficit da Previdência, constituindo-se verdadeiros mecanismos de retrocesso na proteção 
social. Já nos anos 2000, a Previdência Social sofreu mudanças estruturais e não estruturais nas regras de concessão dos benefícios, sendo estabelecidos critérios mais difíceis de aposentadoria. No entanto, houve a inclusão de várias categorias de trabalhadores, como os domésticos, as donas de casa e os micros e pequenos empresários (Silva, 2014).

Pela breve análise, é possível perceber que existem simultaneidades de momentos históricos relevantes no contexto da evolução do Estado e da Previdência Social do país, que pode ser compreendida em cinco fases, conforme foi abordado. Contudo esses elementos históricos, sociais, políticos, econômicos e culturais não são capazes de levar à compreensão da Previdência Social como uma política pública. Nesse caso, ressalta-se a importância dessa pesquisa, uma vez que se destina a compreender essa temática aliada ao campo das políticas públicas.

\section{PROCEDIMENTOS METODOLÓGICOS}

No campo do processo de pesquisa, em linhas gerais, trata-se de uma pesquisa teórica e empírica, com abordagem qualitativa perante o objetivo proposto, predominantemente documental e bibliográfica.

No escopo da pesquisa teórica foi realizada a revisão de literatura. Dentre os nove tipos de revisão de literatura categorizados nas pesquisas de Paré, Trudel, Jaana e Kitsiou (2015), recorreu-se no presente trabalho à revisão do tipo narrativa (narrative review), a qual tem por objetivo identificar o que tem sido escrito por assunto ou tópico com o escopo mais amplo, visando, sobretudo, apresentar a revisão como uma síntese de narrativa.

Nesta pesquisa, foi necessário recorrer à literatura especializada na área para que se pudesse iluminar a análise dos dados empíricos, como artigos, livros, dissertações e teses que foram utilizados como dados bibliográficos. As seguintes temáticas foram pesquisadas: contexto político e social do regime militar, processo de redemocratização (Bresser-Pereira 2009; Schwarcz \& Starling, 2015); a dinâmica da votação da ANC de 1987 (Backer, Azevedo \& Araújo, 2009; Oliveira, Beltrão \& Ferreira, 1997; Sampaio, 2009); e a compreensão das forças políticas na criação da Seguridade Social (Baptista, 1998; Sampaio, 2009).

Para a execução da pesquisa empírica, inicialmente foram coletados os dados primários no site institucional do Congresso, posteriormente foi utilizada a técnica de análise de conteúdo categorial. Este método consiste em um conjunto de técnicas de comunicação com o propósito de encontrar os significados das mensagens por meio de procedimentos sistemáticos. Dentre as diferentes fases da análise de conteúdo, destacam-se 1) pré-análise, 2) exploração do material e 3) tratamento dos resultados (Bardin, 2009).

Na pré-análise, foram feitas a escolha dos dados primários e a leitura flutuante destes a fim de analisar se eles seriam coerentes com as hipóteses de pesquisa. A dinâmica de votação da ANC de 1987 produziu o conjunto de dados primários: anteprojetos, atas das audiências públicas, atos da Mesa da ANC, destaques, emendas, pareceres, projetos (de Constituição, de Decisão), pronunciamentos, questões de ordem, relatórios, requerimentos e sugestões (dos cidadãos, de entidades, de constituintes). Antes mesmo de a Constituinte ser oficialmente institucionalizada, foram criados grupos de estudos e/ou trabalhos para auxiliar a elaboração do texto constitucional, como o GRPS (1986; Oliveira et al., 1997).

O critério da escolha dos dados primários que fizeram parte do corpus consistiu na exaustividade e representatividade, partindo-se do pressuposto de que as atas das reuniões do GRPS (1986) e as atas das audiências públicas seriam suficientes para a compreensão da dinâmica das políticas públicas, especialmente o reconhecimento do problema público e criação da agenda no contexto da Constituinte de 1987. Os demais dados primários foram excluídos por serem predominantemente documentos formais para cumprimento das etapas da ANC, sem discussão e reflexão por parte dos atores envolvidos, constituindo-se apenas de transcrição de momentos políticos específicos. De acordo com Backer et al. (2009), as audiências públicas foram especialmente relevantes nas votações da ANC, pois mesmo que não tivessem o condão de definir o texto final da carta, estabeleceram o patamar dos debates, geraram ideias, muitas das quais foram ao final acatadas pelos constituintes.

$\mathrm{Na}$ etapa de exploração do material, foi realizada a leitura das atas das reuniões e audiências, com base na qual foram feitos relatórios dos dados que facilitaram a feitura da próxima fase de interpretação dos dados. A etapa de tratamento dos resultados e interpretação consistiu na junção da exploração do material com a teoria previamente escolhida. Essa união permitiu interpretar os dados conforme a realidade da formação da Seguridade Social. 


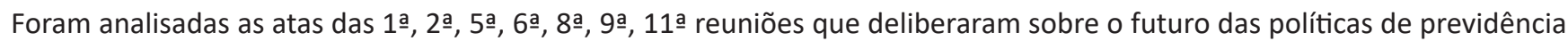
social no Grupo de Trabalho para a Reestruturação da Previdência Social (GRPS, 1986). Em uma segunda etapa foram analisadas as atas das audiências públicas que deliberaram sobre Previdência Social na Subcomissão da Saúde, Seguridade e Meio Ambiente da ANC de 1987, todos os dados primários têm domínio público e podem ser consultados no site institucional do Congresso Nacional. Já os dados da 6a audiência pública são oriundos da Comissão da Ordem Social; 6a a 8a , 10ạ , 11ạ , 13a e 16ạ reuniões da Subcomissão de Saúde, Seguridade e Meio Ambiente.

Figura 2

Esquema dos dados primários

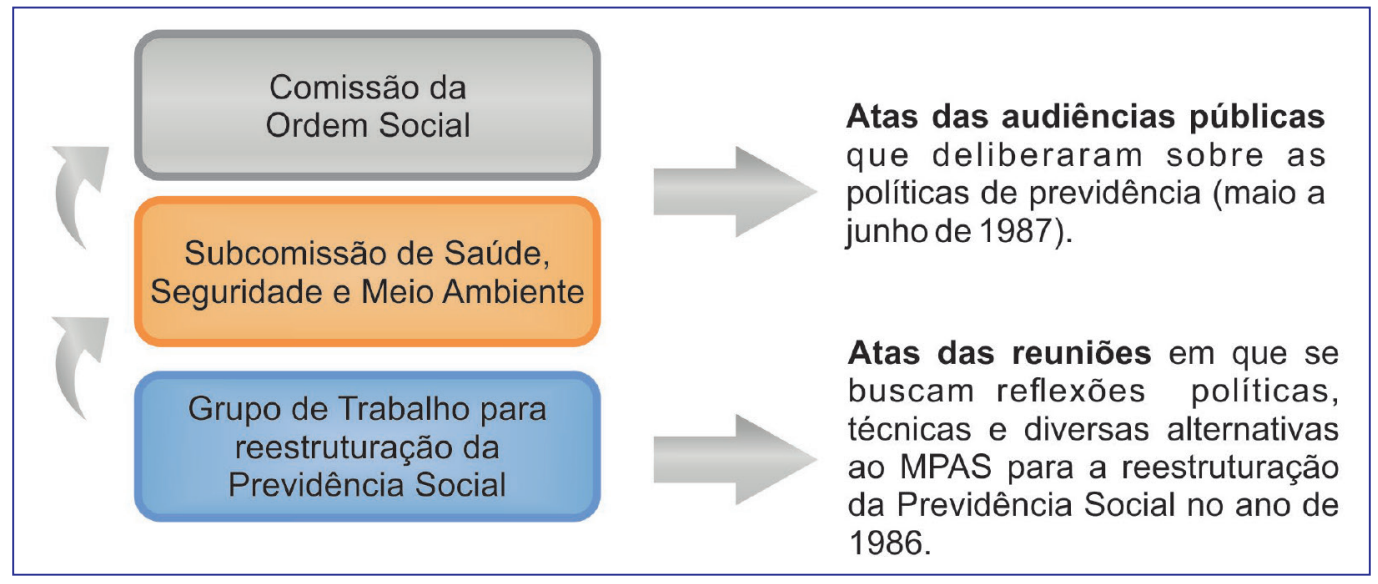

Fonte: Elaborada pelos autores.

Para análise documental dos dados primários, foi utilizada a técnica de análise de conteúdo categorial. Na definição das categorias analíticas, utilizou-se o modelo de categorização de grade fechada, tendo em vista que as categorias são selecionadas no início da análise (Laville \& Dione, 1999).

Quadro 1

Síntese das categorias e subcategorias de análise

\begin{tabular}{|c|l|}
\hline Categorias & \multicolumn{1}{|c|}{ Subcategorias } \\
\hline FLUXO DOS PROBLEMAS & Crises, indicadores, eventos localizadores e feedback de ações. \\
\hline FLUXO DAS SOLUÇÕES & $\begin{array}{l}\text { Viabilidade técnica, viabilidade econômica, aceitação da comunidade } \\
\text { científica, dinâmica das políticas públicas. }\end{array}$ \\
\hline AMBIENTE INTERNACIONAL & Influência das políticas públicas internacionais ou da agenda de outros países. \\
\hline FLUXO DA POLÍTICA & Humor nacional, forças políticas organizadas e mudança de governo. \\
\hline JANELA DE OPORTUNIDADES & Empreendedores da política que geram a convergência dos fluxos. \\
\hline
\end{tabular}

Fonte: Elaborado pelos autores.

As categorias e subcategorias de análise foram, a princípio, extraídas na íntegra do modelo de Múltiplos Fluxos, de Kingdon $(1984,2003)$. Em virtude da necessidade de adaptá-lo à realidade da dinâmica da política pública brasileira, criou-se a categoria de análise "ambiente internacional", que não é oriunda do modelo original de Kingdon (1984) e não se vincula diretamente a nenhum fluxo de problema, soluções e política. 
Figura 3

Esquema analítico dos múltiplos fluxos de Kingdon

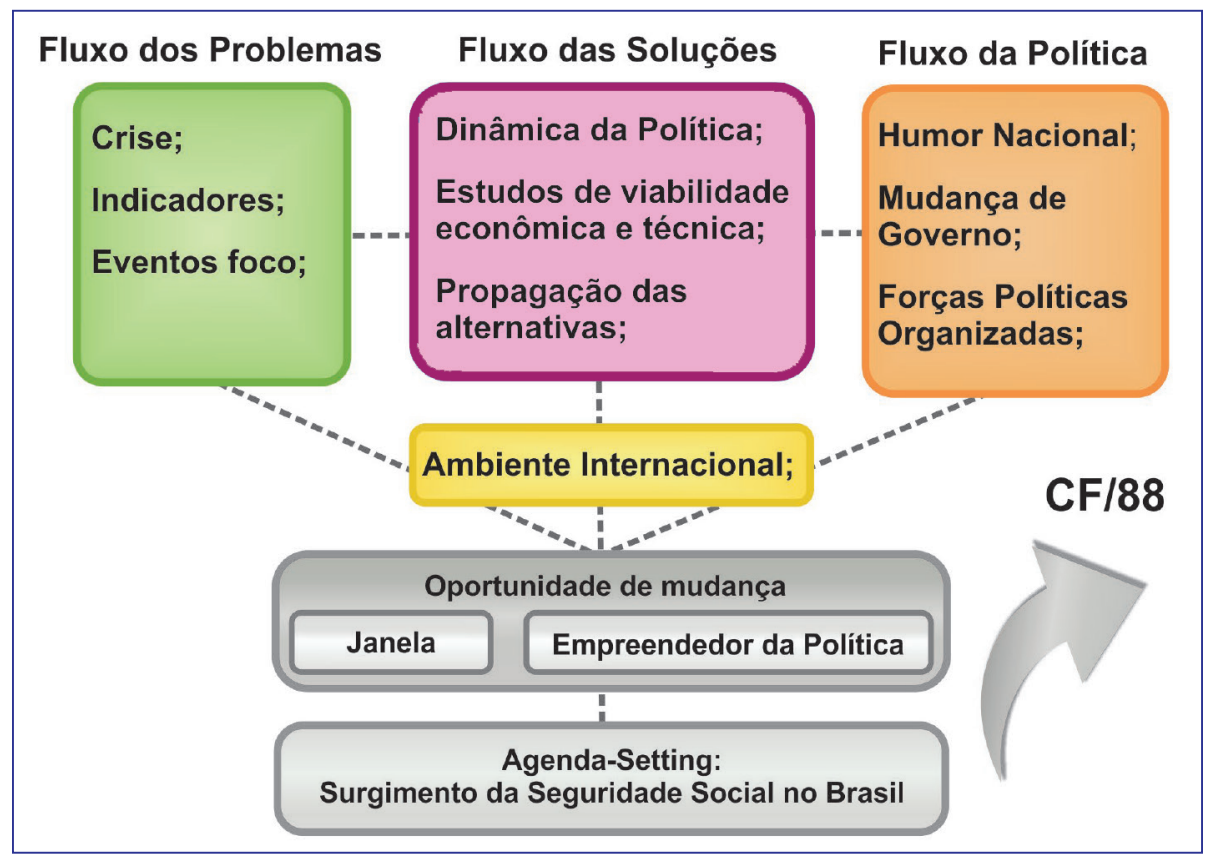

Fonte: Elaborada pelos autores.

\section{DISCUSSÃO E RESULTADOS}

\section{O fluxo dos problemas}

Os indicadores, os eventos-foco e as diferentes crises que compreendem o fluxo dos problemas perpassam a compreensão da revisão de literatura do contexto histórico, político e social das décadas de 1960 a 1980 (Bresser-Pereira, 2009; Schwarcz \& Starling, 2015), além da análise empírica dos dados documentais primários oriundos da ANC de 1987, mais precisamente as discussões da GRPS (1986) e a análise das atas das Audiências Públicas da Subcomissão de Saúde, Meio Ambiente e Seguridade Social, que fazem parte dos Anais da ANC (1987).

A análise do fluxo dos problemas requer a compreensão de que a Previdência Social foi reconhecida como um problema público pelo governo em virtude da evolução histórica da gestão de sua política e pela influência da crise internacional do petróleo da década de 1970, no contexto da ditadura militar, que impactou o financiamento das políticas sociais, em especial as políticas de Previdência Social.

A intervenção militar de 1964 trouxe mudanças significativas para a realidade brasileira, visto que durante mais de vinte anos um novo sistema político concentrado nas mãos das Forças Armadas tomou o controle da presidência da República. Os militares se mantiveram no poder com a manutenção de modelo de desenvolvimento pautado na obtenção de empréstimos internacionais a fim de financiar as políticas internas. Contudo a crise do petróleo instaurada no EUA culminou em políticas de valorização do dólar, impactando as políticas de importação e exportação durante toda a década de 80. Na realidade brasileira, o desequilíbrio das contas externas e a inflação passaram a ser uma crise crônica da economia nacional (Bresser-Pereira, 2009).

Assim, a crise econômica vivida na década de 1980 no Brasil como resquício da crise internacional da década de 1970 impactou diretamente o financiamento das políticas sociais, o que culminou em consequências negativas nas contas previdenciárias. As finanças da Previdência Social tornaram-se um grande problema público e, em 1980, o então presidente João Figueiredo decretou a "falência" do órgão com a criação de um pacote previdenciário para sanar os déficits. Destacavam-se medidas como início da contribuição pelos aposentados e pensionistas, aumento do percentual de contribuição dos servidores públicos e aumento da contribuição sobre as folhas de salário (GRPS, 1986). 
Sob outro aspecto, sabe-se que, desde a sua origem, o sistema previdenciário brasileiro teve sucessivas mudanças e, consequentemente, fases em sua gestão: inicialmente de vinculação da empresa com as CAPs, de 1923 a 1930; de vinculação da categoria profissional com os IAPs, de 1930 a 1960; de unificação institucional com a Lei Orgânica da Previdência Social (LOPS) em 1966 e da criação do INPS (Oliveira et al., 1997).

A análise empírica evidenciou que a Previdência viveu crises cíclicas de gestão e financiamento, provocadas por fraudes, erros e má administração. Esses problemas eram superados eventualmente pelo crescimento econômico, em que a massa salarial e o número de empregados tinham um elevado aumento, mascarando as contas públicas. Entretanto durante a boa fase não eram adotadas medidas suficientes de racionalização e ordenação do sistema, o qual se mantinha refém de reviravoltas financeiras (ANC, 1987).

Assim, o fluxo dos problemas correlaciona indicadores econômicos do déficit previdenciário, crise financeira da economia brasileira de maneira ampla e a própria crise da Previdência Social brasileira, além de eventos-foco como o reconhecimento da falência da Previdência Social, que mobilizou no âmbito político possíveis alternativas para reformulação dessa política.

\section{O fluxo das soluções}

Importa analisar as alternativas e soluções por meio da análise dos dados primários coletados nas propostas formuladas pelo GRPS (1986), as possíveis soluções oriundas das atas das Audiências Públicas da Subcomissão de Saúde, Meio Ambiente e Seguridade Social e da Comissão da Ordem Social, que fazem parte do Diário da Assembleia Nacional Constituinte de 1987 (ANC, 1987). São discussões e/ou alternativas propostas por representantes dos sindicatos, aposentados, comunidade científica e membros do governo, que foram escolhidos para propor soluções sobre o futuro da Previdência Social na CF/88.

Com o reconhecimento do problema público, surgiram distintas alternativas pautadas nos estudos de viabilidade técnica e econômica realizados no GRPS, tais como: estabelecimento de novas diretrizes para o financiamento da Previdência; reestruturação da previdência dos trabalhadores rurais; necessidade de formação de um corpo burocrático e/ou administrativo focado na gestão dos diferentes órgãos administrativos; criação de mecanismos de participação da sociedade civil na formulação e no acompanhamento das políticas; além da proposta de criação do Ministério da Seguridade Social (GRPS, 1986).

As distintas alternativas foram propagadas em diferentes arenas: no GRPS de 1986, no Conselho Superior da Previdência Social, na Comissão da Ordem Social e Subcomissão da Saúde, Meio Ambiente e Seguridade inseridos na ANC de 1987.

\section{Figura 4}

Relação entre os dados analisados e a dinâmica das políticas públicas de previdência social

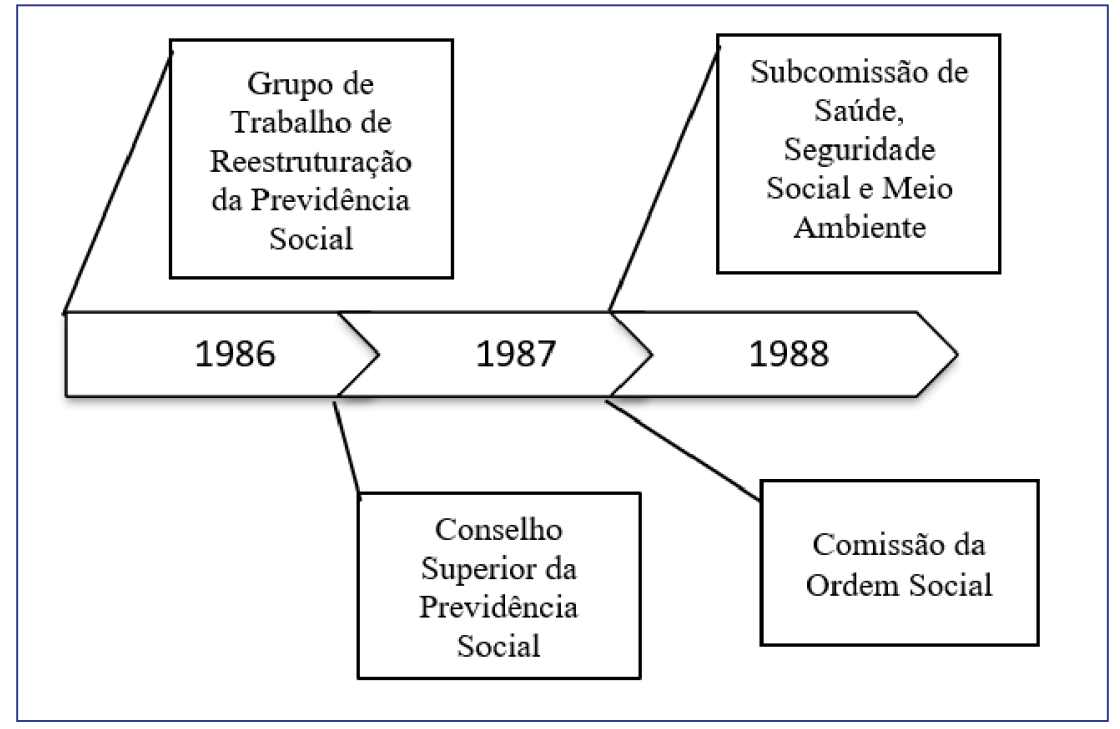

Fonte: Elaborada pelos autores. 
No âmbito da análise dos dados oriundos do GRPS (1986), verifica-se a defesa da proposta de criação da Seguridade Social encabeçada, em sua maioria, pelos próprios membros do Ministério presentes neste grupo, como Sulamis Daim, Dorothea Werneck e Eleutério Neto. Em oposição, os representantes do Gabinete Civil eram avessos à criação de um Ministério da Seguridade Social, prevendo que a criação de um órgão único gerindo as três áreas poderia formar uma estrutura social muito forte frente às outras áreas de proteção pelo Estado.

Além dos membros do governo, foram convidados especialistas que constituíram um grupo formado por conhecedores das questões sociais e previdenciárias, assim como acadêmicos e pesquisadores do Instituto Universitário de Pesquisas do Rio de Janeiro (IUPERJ), Universidade Estadual de Campinas (UNICAMP), Instituto Brasileiro de Geografia e Estatística (IBGE), Empresa de Tecnologia e Informações da Previdência (DATAPREV) e Fundação Oswaldo Cruz (FIOCRUZ). A presença de tais pessoas visava contribuir tecnicamente com propostas que foram analisadas e apresentavam a discussão sobre a viabilidade de aplicação e a realidade do cenário brasileiro. Tratava-se, portanto, de um grupo que a princípio não tinha definido posição contrária ou favorável às propostas, mas que indicava estudos técnicos e contribuía, com relevância, nas discussões das reuniões.

Além dos representantes anteriores, havia o grupo dos trabalhadores formado por representantes do Comando Geral dos Trabalhadores (CGT), Central Única dos Trabalhadores (CUT), da Confederação Nacional dos Trabalhadores na Agricultura (CONTAG), dos trabalhadores rurais, da Federação Nacional e Sindicato dos Estivadores e representantes dos aposentados e pensionistas. Uma das principais características deste grupo era a sua resistência à criação da Seguridade, em especial às propostas oferecidas pelo grupo do governo.

Consoante a ata da $6^{\circ}$ reunião do GRPS (1986), Moacyr Oliveira (representante do Ministério da Previdência e Assistência Social [MPAS]) faz menção, em diferentes passagens, às deliberações, na Convenção n. 102 da Organização Internacional do Trabalho (OIT), sobre a necessidade de participação paritária, do universalismo e outros conceitos extraídos da convenção internacional para servir de base para a Seguridade brasileira. Ainda nessa reunião, o membro Luiz Viegas Lima (representante dos aposentados e pensionistas) ressaltou que não se deveria contraditar a decisão da OIT, uma vez que esta aconselhava a criação de uma rede de Seguridade Social no mundo.

Em compensação, Annibal Fernandes (representante dos trabalhadores) assinalava que a recomendação pela OIT para a criação da Seguridade Social não havia se tornado pública pelos atores que deliberaram no GRPS, tampouco teria sido contraditada e analisada de acordo com a realidade brasileira:

No entanto, a esses elementos de progresso há naturalmente dificuldades, senão não haveria necessidade de se vir até a 11a reunião. A 1a delas é que, de certa forma, a Comissão se limitou a estudos prévios que não foram totalmente revelados; alguns nos foram entregues mas há um segredo de polichinelo de um estudo da OIT que circula de mão em mão e está sendo mantido como se fosse um segredo de Estado Maior, um projeto da bomba atômica brasileira, mas na verdade partes dessas limitações e das dificuldades que temos de chegar a um consenso sobre tudo, uma vez que sobre grande parte estamos em consenso, se devem a um estudo da OIT aos quais foram, talvez, entregues elementos incompletos sobre a realidade brasileira. Talvez ou certamente (GRPS, 1986, p. 987).

É peculiar o surgimento dos ideais de Seguridade Social no Brasil, visto que, no final da década de 1980 e início de 1990, os principais países da Europa e os EUA, após um longo período de crise, estavam vivendo o auge do liberalismo econômico com as políticas de Margareth Thatcher e Ronald Regan, os quais paulatinamente criaram políticas que minimizaram o Estado de bem-estar social (Rocha, 2013).

Portanto, consoante a literatura e a análise empírica, é inegável, de certa forma, a influência da OIT ao pressionar os governos latino-americanos à criação da Seguridade Social. Mesmo que essa influência não fosse plenamente compartilhada pela comunidade e em certa medida não muito bem recepcionada pelos membros do GRPS, não se podem negar a postura da OIT e sua influência enquanto organismo internacional sobre a decisão política de vários países do mundo na promoção da propagação das políticas de bem-estar social concretizadas pelas Seguridade Social. Talvez esse organismo tenha sido o maior precursor dessa rede de políticas integradas que passaram a ser criadas visando à proteção social de forma universal e indiscriminada. 
O GRPS foi uma arena democrática em que se observou ampla participação de diferentes representantes da sociedade civil. Ao longo das discussões, foram apresentados muitos estudos técnicos e novas propostas para a reestruturação da Previdência Social. Sua relevância fica evidente ao se constatar que o relatório final foi direcionado ao debate na ANC e que alguns participantes foram convidados a fazer exposições nas Audiências Públicas das Subcomissões e Comissão da Ordem Social.

Nos debates presentes nesses ambientes institucionais, foram apresentados distintos estudos técnicos e econômicos visando, sobretudo, sanar, a princípio, o problema público do déficit previdenciário por meio das propostas dos novos planos de benefícios e custeio da Previdência Social. Não havia nessas arenas um consenso sobre a criação da Seguridade Social, apenas os representantes do governo estimulavam a criação dessa política integrada. Entretanto, com o passar do tempo, diante do amadurecimento dos estudos e das deliberações do GRPS, a criação da Seguridade Social tornou-se unanimidade entre os membros e no âmbito das audiências públicas. Já que se tratava de uma deliberação política, a Seguridade passou a ser defendida por diferentes atores sociais (constituintes e convidados).

Soma-se a esses fatores a influência do ambiente internacional no crescimento dos ideais do welfare state (Estado de bem-estar social) com a criação de políticas de Seguridade Social e que foram fortalecidos com a Carta dos Direitos Humanos de 1948 e pela Convenção n. 102 da OIT. Desse modo, os ideais chegaram ao Brasil no mesmo período de redemocratização e reconstrução das bases das políticas sociais, o que causou um forte clamor nas arenas institucionais como GRPS e ACN de 1987.

\section{O fluxo da política}

Com a compreensão dos fluxos de problemas e alternativas, importa saber que o fluxo da política possui uma dinâmica própria. O humor nacional, a mudança de governo e as forças políticas organizadas permitem entender a dinâmica ocorrida no contexto da formação das bases da política de Previdência, em especial o comportamento político antes e durante a ANC de 1987.

O humor nacional vivido no período de redemocratização e as mobilizações sociais, principalmente o movimento das Diretas Já, são elementos que indicam o esgotamento da autocracia na sociedade brasileira e a esperança nos ideais democráticos que poderiam mudar os rumos do Brasil (Sampaio, 2009). No caso da criação das políticas de Seguridade Social, o ambiente internacional era favorável (influência da OIT), assim como o nacional. Mesmo que tenha sido encabeçada pelos representantes do governo, a proposta da integração das três políticas (Saúde, Assistência e Previdência) ganhou força com os demais atores sociais que estavam dispostos a criar as novas bases de construção desta política.

A mudança de governo com a primeira eleição indireta para presidente da República depois do período militar foi um momento de grande tensão e contradição, pois, apesar da vitória de Tancredo Neves, é o vice-presidente José Sarney quem toma posse em virtude do falecimento do presidente eleito, o que provocou mais instabilidade política.

Nesse escopo, as forças políticas organizadas podem ser observadas em arenas distintas. No GRPS, havia um corpo burocrático e técnico reunido para traçar novos planos para a Previdência Social. O GRPS constituiu-se uma arena democrática, visto que foi constatada a ampla participação de diferentes representantes da sociedade civil. Ao longo das discussões, foram apresentados muitos estudos técnicos e novas propostas para a reestruturação da Previdência Social. A sua relevância fica evidente com a percepção de que o relatório final foi direcionado ao debate na ANC de 1987 e da participação de alguns membros que foram convidados a fazer exposições nas Audiências Públicas das Subcomissões e Comissão da Ordem Social (ANC, 1987; GRPS, 1986).

A ANC foi uma etapa muito rica na vida política brasileira, uma vez que foi organizada em Audiências Públicas cuja atenção é despertada tanto pela diversidade de participantes quanto pelas inúmeras propostas que surgiram ao longo dos debates. De acordo com a gênese da CF/88, exposta por Oliveira et al. (1997), as comissões consistiam em plenários compostos pelos partidos políticos, na proporção das suas forças e alianças políticas. As comissões deveriam seguir as regras do regimento geral e dos atos criados pela Câmara, assim, as comissões que poderiam dispor de algumas de suas atribuições. Ao final, as comissões deveriam apresentar relatórios para deliberação coletiva e votação do texto constitucional (Schwarcz \& Starling, 2015).

As subcomissões, por sua vez, eram um desdobramento das comissões e poderiam aprofundar o estudo e o debate em algum assunto reconhecido como relevante pelos constituintes. De forma específica, a Comissão da Ordem Social contou com três subcomissões: Direitos dos Trabalhadores e Servidores Públicos; Subcomissão de Saúde, Seguridade e Meio Ambiente; Subcomissão dos Negros, População Indígena, Pessoas Deficientes e Minorias. Cada subcomissão organizou a sua pauta de audiências e formou o seu corpo de participantes convidados (Backer et al., 2009). 
A análise das audiências da subcomissão permite concluir que as discussões sobre a Previdência e a Seguridade Social refletiram momentos de pouca deliberação e muita exposição. A ocorrência de poucas deliberações deve-se ao reduzido número de encontros - apenas seis -, dentre os quais, somente um destinou-se exclusivamente à Seguridade e um à Previdência Social. Tal fato reforça a hipótese de que a criação da Seguridade Social foi, de fato, uma mobilização do governo (MPAS), que, ao longo das reuniões do GRPS, convenceu os membros de que seria a melhor saída. Quando da deliberação na Assembleia, a ideia já estava formada, só restava compartilhar com os demais constituintes qual seria o plano do governo para a sua implantação.

\section{A janela de oportunidades e o empreendedor da política}

No âmbito desta pesquisa, a ANC de 1987 pode ser analisada de acordo com o conceito de janela induzida, visto que foram reunidas circunstâncias históricas, sociais e políticas que induziram esse momento, qual seja, a oportunidade de construir as novas bases constitucionais para o Brasil. Por meio dela, foi possível realizar a reestruturação de todo o modelo político, jurídico e institucional brasileiro. A ANC foi o momento oportuno para que diferentes partidos e políticos de distintas ideologias pudessem construir um novo panorama constitucional no campo político.

Os principais atores sociais envolvidos com a Previdência e a Seguridade foram: representantes do corpo técnico burocrático do MPAS representados por Márcia Mazolli, Maria Emília Azevedo, Obed Dornellas e, na alta cúpula, o gestor Reinhold Stephanes. O ex-Ministro Raphael de Almeida Magalhães e o constituinte Eduardo Jorge foram os atores políticos principais. O ex-ministro foi quem mais se destacou como o empreendedor da política, tendo sido o responsável por direcionar as políticas do MPAS a fim de criar o ambiente propício à criação da Seguridade. Nas arenas políticas em que participou, foi o maior defensor da integralização das políticas da Saúde, Assistência e Previdência.

\section{A convergência dos fluxos e reflexões}

Em 05 de outubro de 1988 foi promulgada a Constituição Federal de 1988, a qual recentemente completou 32 anos. Não obstante os entraves à sua efetivação, a CF/88 representou a consolidação do Estado Democrático de Direito, fortaleceu a democracia, a cidadania, instituiu a promoção da dignidade humana e aumentou significativamente o escopo social das políticas do Estado brasileiro. Ela foi responsável pela inovação constitucional ao criar a Seguridade Social no Brasil.

A convergência dos fluxos permite a compreensão da formação da agenda de políticas públicas na década de 1980, especialmente como a Previdência Social torna-se um elemento da Seguridade no âmbito das políticas públicas na CF/88. Os elementos perpassam fatores políticos, sociais e econômicos de níveis nacional e internacional. Esses elementos reunidos no contexto histórico de redemocratização possibilitaram a construção de um desenho constitucional universal, democrático e igualitário. A união desses fluxos por meio da janela de oportunidades foi possível graças ao empreendedor da política, o ministro do MPAS, Raphael Magalhães, que, desde a criação do GRPS em 1986, foi o grande articulador dessa política nas diferentes arenas políticas.

Diante da análise realizada, importa fazer algumas reflexões a respeito do contexto de criação da Seguridade Social e possíveis similitudes entre a criação da Seguridade Social em 1988 e a recente reforma da Previdência Social de 2019.

A formação da Seguridade Social é produto constitucional oriundo de um momento anterior de grande crise econômica e de gestão que proporcionaram a possibilidade de mudanças. A Previdência Social apresentou sinais de ruptura com uma gestão caótica e desorganizada, evidenciada pela criação de sucessivos ministérios e órgãos públicos, somando-se a tudo isso a ausência de um corpo burocrático especializado em cada área (Saúde, Previdência e Assistência).

Juntam-se a esses fatores pouca mobilização e participação social das pessoas diretamente afetadas pelas políticas de Seguridade. Ao contrário das políticas de Saúde, que historicamente apresentam seus defensores, os estudos não evidenciaram os defensores da Seguridade Social e/ou Previdência Social enquanto uma política de bem-estar para o trabalhador. Pelo contrário, a maior parte dos atores envolvidos estava preocupada com as finanças públicas e com o equilíbrio econômico e atuarial da Previdência. Curiosamente, a influência internacional (criação de um sistema de Seguridade Social) no momento histórico adequado, qual seja, a redemocratização do país, foi o combustível que a política brasileira precisava para ampliar a sua rede de proteção social. Tudo isso só foi possível graças aos empreendedores da política, como dito, Raphael Magalhães, no âmbito da Previdência Social, e Ulysses Guimarães, que se revelou um grande articulador e também defensor do aspecto social assumido pelo texto constitucional que estava sendo votado na ANC. 


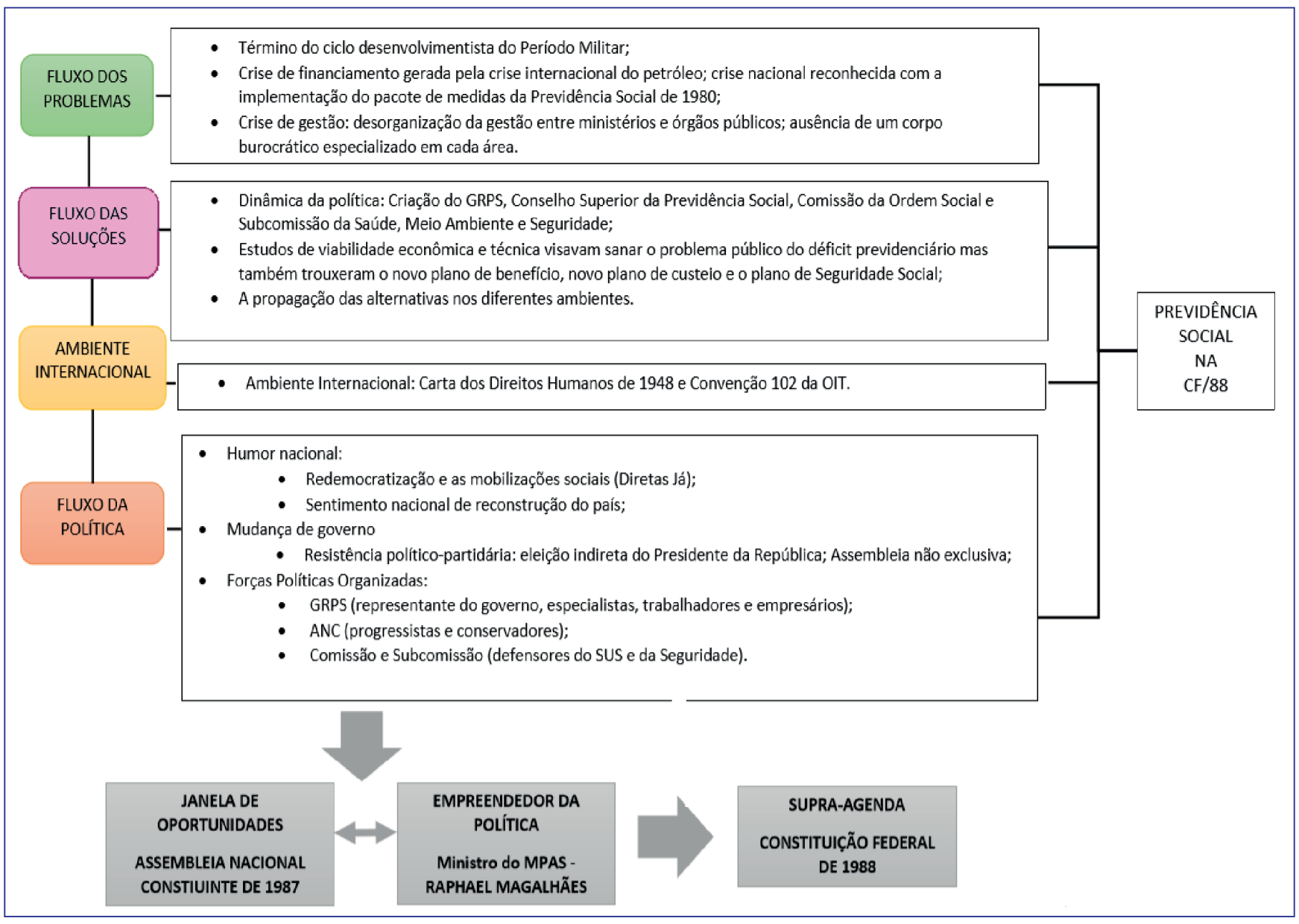

Fonte: Elaborada pelos autores.

Assim, visualiza-se a formação de uma Seguridade Social com um objetivo de proteção social por meio de amplas políticas de Saúde, Assistência e Previdência que precisariam ser implementadas após o texto constitucional. Porém, diante dos fatos, a Seguridade Social já nasce em meio a uma histórica crise de gestão: burocratas insatisfeitos com os ministérios e órgãos aos quais estavam atribuídos; o novo texto constitucional inaugurou uma nova frente de benefícios e financiamento que precisariam ser devidamente implantados a fim de evitar futuras rupturas. Ou seja, era necessário concretizar o acordo social firmado pela $\mathrm{CF} / 88$.

Porém, após a promulgação da Constituição, observou-se que o desequilíbrio financeiro e a falta dos articuladores em prol da construção de um modelo de Seguridade Social engajados com a proteção social fizeram com que, nos trinta anos de Seguridade Social, a Previdência sofresse inúmeras reformas paramétricas. Conforme analisado por Silva, Teixeira e Costa (2019), algumas reformas foram interpretadas como incrementais (Emendas Constitucionais 20/1998; 41/2003; 47/2005; Lei no 13.183/2015; Lei no 12.618/ 2012), visto que tentaram acompanhar as mudanças demográficas e econômicas. No curto prazo, essas alterações aumentaram a morosidade e a burocratização do sistema, desaguando em judicialização e aumento das despesas públicas no âmbito da atual gestão previdenciária, gerando até mesmo mais insumo para narrativas de justificação de outras reformas, mais profundas.

Todos esses fatores reunidos indicam que os atuais argumentos a favor de reformas previdenciárias são os mesmos de há mais de trinta anos: (des)equilíbrio financeiro e atuarial, solvência das contas públicas e necessidade de reformular a concessão dos benefícios previdenciários, como já visto ao longo deste trabalho. O Projeto de Emenda Constitucional n. 286 (rejeitado em 2016) e o Projeto de Emenda Constitucional n. 6 de 2019 (aprovado como Emenda à Constituição n 103 de 2019) 
possuem alterações mais robustas e menos incrementais como as reformas anteriores, ambos apresentam regras rígidas para a concessão de benefícios previdenciários, mudando muito pouco no que diz respeito ao financiamento do sistema previdenciário. Contudo a recente reforma tem potencial para colocar em risco a rede de proteção constitucional conforme aprovada na ANC, especialmente a ideia de um sistema previdenciário coletivo, visando proteger toda a sociedade; pautado, sobretudo, na ótica da proteção social e não contratual.

\section{CONSIDERAÇÕES FINAIS}

Esse artigo foi construído sob as bases teóricas da policy agenda-setting com as devidas adaptações à realidade da dinâmica da política pública brasileira. Por meio da discussão teórica foi possível constatar que o campo de análise de políticas públicas no Brasil está em franca expansão, especialmente a compreensão da formação das agendas públicas, além da carência de estudos que abordam a relação entre a CF/88 e o ciclo político.

A análise dos fluxos (problemas, soluções, política), criados por Kingdon (1984) com a inserção da influência internacional indicou que a Previdência Social enquanto um problema público da década de 1970 e 1980 estava atrelada a fatores econômicos e de gestão. Porém, quando esse problema tocou a agenda pública, distintas alternativas foram formuladas, inclusive a ideia de expansão da cobertura social por meio da criação da Seguridade Social.

No campo político, a rede de proteção chamada Seguridade ganhou força no momento oportuno da janela de oportunidades (ANC) pelos empreendedores da política, isto é, atores sociais (políticos e o corpo burocrático estatal), que foram influenciados pela dinâmica internacional (welfare state e OIT) e pelos ideais da social-democracia que chegaram ao Brasil no período da redemocratização.

Importante destacar a realização de estudos sobre agenda-setting e Seguridade Social, como os de Menezes (2012) e Cruz (2015), que retratam a formação das políticas da Assistência Social e da Saúde como parte integrante da Seguridade Social na CF/88. A produção acadêmica da área da Administração Pública sobre a temática específica da Previdência Social possui como abordagem as perspectivas teóricas que se relacionam com teorias ligadas ao Estado de bem-estar-social, a fatores econômicos, fatores jurídicos e temas reformistas da Previdência Social (Silva, Tavares \& Lopes, 2018). Portanto reitera-se a importância de novos estudos que unam as temáticas: políticas públicas, agenda pública e Previdência Social; sobretudo porque as reformas neste campo continuam a ser propostas, influenciando muitas vezes o resultado da política e o pacto constitucional.

Por fim, espera-se que este trabalho tenha contribuído para diferentes áreas do conhecimento, em especial os campos da Administração Pública e da Ciência Política, tanto com a análise teórica sobre as possibilidades de adaptação do modelo de Múltiplos Fluxos, de Kingdon, à realidade brasileira, quanto a análise empírica da formação da Previdência Social enquanto uma política pública no campo da Seguridade Social na década de 1980 e na CF/88.

\section{AGRADECIMENTOS}

O presente trabalho foi realizado com apoio da Coordenação de Aperfeiçoamento de Pessoal de Nível Superior - Brasil (CAPES) Código de Financiamento 001. Financiamento da Bolsa de Mestrado da Raquel Andrade Silva de Oliveira. 


\section{REFERÊNCIAS}

Assembleia Nacional Constituinte. (1987). Ata da reunião de instalação da Comissão de Sistematização. Brasília, DF: Congresso Nacional, Senado Federal. Recuperado de https://www.senado.leg. $\mathrm{br} /$ publicacoes/anais/constituinte/sistema.pdf

Backer, A. L., Azevedo, J. C., \& Araújo, J. C. (2009). Audiências Públicas na Assembleia Nacional Constituinte: a sociedade na tribuna (Série coleções especiais. Obras comemorativas, n. 3). Brasília, DF: Câmara dos Deputados.

Baptista, T. W. F. (1998). Seguridade Social no Brasil. Revista de Serviço Público, 49(3), 99-119. Recuperado de https://doi.org/10.21874/ rsp.v49i3.373

Bardin, L. (2009). Análise de Conteúdo. Lisboa, Portugal: Edições 70.

Baumgartner, F., \& Jones, B. (1993). Agendas and instability in American Politics. Chicago, Illinois: University of Chicago Press.

Boschetti, I. (2009). Seguridade social no Brasil: conquistas e limites à sua efetivação. In Conselho Federal de Serviço Social (Org.), Serviço Social: direitos sociais e competências profissionais. Brasília, DF: Ed. UnB. Recuperado de http://www.sindifisconacional.org.br/images/ justica_fiscal/RGPS/textos_artigos/seguridade-social-no-brasil.pdf

Bresser-Pereira, L. C. (2009). Construindo o Estado Republicano: Democracia e reforma da gestão pública. Rio de Janeiro, RJ: FGV.

Capella, A. C. N. (2007). Perspectivas teóricas sobre o processo de formulação de Políticas Públicas. In G. Hochman, M. Arretche, M., \& Marques, E. (Org.), Políticas Públicas no Brasil. Rio de Janeiro, RJ: Editora Fiocruz.

Cobb, R. W., \& Elder, C. D. (1972). Participation in American politics: the dynamics of agenda-building. Baltimore, Maryland: Johns Hopkins University Press.

Cohen, M., March, J., \& Olsen, J. (1972). A Garbage Can Model of Organizational Choice. Administrative Science Quarterley, 17(1), 1-25. Recuperado de https://doi.org/10.2307/2392088

Constituição Federal de 1988. (1988). Brasília, DF: Senado Federal. Recuperado de http://www.planalto.gov.br/ccivil_03/constituicao/ constituicaocompilado.htm

Costa, N. R. (2009). A proteção social no Brasil: universalismo e focalização nos governos FHC e Lula. Ciência e Saúde Coletiva, 14(3), 693-706. Recuperado de https://doi.org/10.1590/ S1413-81232009000300002

Cruz, S. A. M. (2015). A criação do Sistema Único de Saúde (SUS): o engendramento de uma policy network pelo movimento sanitário (Tese de Doutorado). Universidade Candido Mendes, Rio de Janeiro, RJ.

Emenda Constitucional $n^{\circ} 20$, de 15 de dezembro de 1998. (1998). Modifica o sistema de previdência social, estabelece normas de transição e dá outras providências. Recuperado de http://www. planalto.gov.br/ccivil_03/constituicao/emendas/emc/emc20.htm

Emenda Constitucional $n^{\circ} 41$, de 19 de dezembro de 2003. (2003). Modifica os arts. 37, 40, 42, 48, 96, 149 e 201 da Constituição Federal, revoga o inciso IX do $\S 3$ do art. 142 da Constituição Federal e dispositivos da Emenda Constitucional no 20, de 15 de dezembro de 1998, e dá outras providências. Recuperado de http://www. planalto.gov.br/ccivil_03/constituicao/emendas/emc/emc41.htm

Emenda Constitucional $n^{\circ} 47$, de 5 de julho de 2005. (2005). Altera os arts. 37, 40, 195 e 201 da Constituição Federal, para dispor sobre a previdência social, e dá outras providências. Recuperado de http:// www.planalto.gov.br/ccivil_03/constituicao/Emendas/Emc/emc47.htm

Emenda Constitucional $n^{\circ} 103$, de 12 de novembro de 2019. (2019). Altera o sistema de previdência social e estabelece regras de transição e disposições transitórias. Recuperado de http://www. planalto.gov. br/ccivil_03/constituicao/emendas/emc/emc103.htm

Grupo de Trabalho para Reestruturação da Previdência Social. (1986). Rumos da Nova Previdência: anais. Brasília, DF: Ministério Público de Assistência Social.

Jones, M. D., Peterson, H. L., Pierce, J. J., Herweg, N., Bernal, A., Raney, H, L. ... Zahariadis, Nikolaos. (2016). A River Runs Throught it: a Multiple Streams Meta Review. The Policy Studies Journal, 44(1), 13-36. Recuperado de https://doi.org/10.1111/psj.12115

Kingdon, J. W. (1984). Agendas, Alternatives, and Public Policies. Boston, MA: Little Brown \& Company.

Kingdon, J. W. (2003). Agendas, Alternatives, and Public Policies. New York, NY: Harper Collins.

Lanzara, A. P. (2016). Estado, trabalho e seguridade social no Brasil: legados, transformações e desafios. Revista do Serviço Público, 67(1), 31-54. Recuperado de https://doi.org/10.21874/rsp.v67i1

Laville, C., \& Dionne, J. (1999). A construção do saber: manual da metodologia de pesquisa em ciências humanas. Belo Horizonte, MG: Editora UFMG.

Lei no 12.618, de 30 de abril de 2012. (2012). Institui o regime de previdência complementar para os servidores públicos federais titulares de cargo efetivo, inclusive os membros dos órgãos que menciona; fixa o limite máximo para a concessão de aposentadorias e pensões pelo regime de previdência de que trata o art. 40 da Constituição Federal; autoriza a criação de 3 (três) entidades fechadas de previdência complementar, denominadas Fundação de Previdência Complementar do Servidor Público Federal do Poder Executivo (Funpresp-Exe), Fundação de Previdência Complementar do Servidor Público Federal do Poder Legislativo (Funpresp-Leg) e Fundação de Previdência Complementar do Servidor Público Federal do Poder Judiciário (Funpresp-Jud); altera dispositivos da Lei no 10.887, de 18 de junho de 2004; e dá outras providências. Recuperado de http:// www.planalto.gov.br/ccivil_03/_ato2011-2014/2012/lei/l12618.htm

Lei no 13.183, de 4 de novembro de 2015. (2015). Altera as Leis nos 8.212, de 24 de julho de 1991, e 8.213, de 24 de julho de 1991, para tratar da associação do segurado especial em cooperativa de crédito rural e, ainda essa última, para atualizar o rol de dependentes, estabelecer regra de não incidência do fator previdenciário, regras de pensão por morte e de empréstimo consignado, a Lei no 10.779 , de 25 de novembro de 2003, para assegurar pagamento do segurodefeso para familiar que exerça atividade de apoio à pesca, a Lei no 12.618, de 30 de abril de 2012, para estabelecer regra de inscrição no regime de previdência complementar dos servidores públicos federais titulares de cargo efetivo, a Lei no 10.820, de 17 de dezembro 
de 2003, para dispor sobre o pagamento de empréstimos realizados por participantes e assistidos com entidades fechadas e abertas de previdência complementar e a Lei no 7.998, de 11 de janeiro de 1990; e dá outras providências. Recuperado de http://www.planalto.gov. br/ccivil_03/_Ato2015-2018/2015/Lei/L13183.htm

Lobato, L. V. C. (2016). Políticas sociais e modelos de bem-estar social: fragilidades do caso brasileiro. Saúde e Debate, 40(esp.), 87-97. Recuperado de https://doi.org/10.1590/0103-11042016S08

Menezes, A. O. (2012). Mudanças institucionais da seguridade social no Brasil: uma análise comparada entre o Sistema Único de Saúde e o Sistema Único de Assistência Social (Dissertação de Mestrado). Universidade de Brasília, Brasília, DF.

Oliveira, F. E. B., Beltrão, K. I., \& Ferreira, M. G. (1997). Reforma da Previdência (Texto para discussão, 508). Rio de Janeiro: IPEA/INPES.

Oliveira, W. J. F. (2008). Agendas internacionais, mecanismos institucionais e referenciais ideológicos nas políticas públicas de gestão ambiental. Revista de Política Pública São Luís, 12(1), 107-116.

Organização Internacional do Trabalho. (1952). C102 - Normas Mínimas da Seguridade Social. Recuperado de https://www.ilo.org/brasilia/ convencoes/WCMS_235192/lang--pt/index.htm

Paré, G., Trudel, M.C., Jaana, M., \& Kitsiou, S. (2015, março). Synthesizing Information Systems Knowledge: A Typology of Literature Reviews. Information \& Management, 52(2), 183-199. Recuperado de https://doi.org/10.1016/j.im.2014.08.008

Pelarez, V., Invernizzi, N., Fuck, M. P., Bagatolli, C., \& Oliveira, M, R. (2017). A volatilidade da agenda de políticas de C\&T no Brasil. Revista de Administração Pública, 51(5), 788-809. Recuperado de https:// doi.org/10.1590/0034-7612162639

Projeto de Emenda à Constituição, $n^{\circ} 287$ de 2016. (2016). Altera os arts. 37, 40, 109, 149, 167, 195, 201 e 203 da Constituição, para dispor sobre a seguridade social, estabelece regras de transição e dá outras providências. Recuperado de http://www.camara.gov.br/proposicoesWeb/prop_ mostrarintegra;jsessionid=0EF6691E6AA30A8F8446B7B47DA870E3. proposicoesWebExterno1?codteor=1514975\&filename $=P E C+287 / 2016$

Rocha, A. S. (2013). Genealogia da Constituinte: do autoritarismo à democratização. Lua Nova, 88, 29-87. Recuperado de https://doi. org/10.1590/S0102-64452013000100004

Rua, M. D. G. (2009). Políticas Públicas. Florianópolis, SC: UFSC.

Sabatier, P. A. (1999). Theories of the Policy Process. Denver, Colorado: Westview Press.

Sabatier, P. A. (2007). Theories of the Policy Process (2a ed.). Denver, Colorado: Westview Press.
Sabatier, P. A., \& Weible, C. M. (2014). Theories of the Policy Process (3a ed.). Denver, Colorado: Westview Press.

Sampaio, P. A. (2009). Para além da ambiguidade: uma reflexão histórica sobre a CF/88. In J. C. Cardoso Junior (Org.), A constituição brasileira de 1988 revisitada: recuperação histórica e desafios atuais das políticas públicas nas áreas econômica e social. Brasília, DF: Ipea.

Schwarcz, L., \& Starling, H. M. (2015). Brasil: uma biografia. São Paulo, SP: Companhia das Letras.

Secchi, L. (2014). Políticas Públicas: conceitos, esquemas de análises, casos práticos (2a ed.). São Paulo, SP: Cengage Learning.

Silva, L. L. (2014). Formação do Sistema Previdenciário Brasileiro: fatores históricos e econômicos (Dissertação de Mestrado). Universidade Federal de Viçosa, Viçosa, MG.

Silva, R. A., Tavares, B., \& Lopes, M. E. O. (2018, junho). As perspectivas acadêmicas da trajetória das Políticas Públicas de Previdência Social no Brasil. In Anais do $4^{\circ}$ Encontro Brasileiro de Administração Pública (EBAP), Viçosa, MG. Recuperado de http://www.ebap.ufv.br/index. php/ebap/vebap/paper/viewFile/196/52

Silva, R. A., Teixeira, E. A., \& Costa, T. M. T. (2019). As políticas de previdência social sob a ótica do modelo incremental. Nucleus, 16(2), 171-182. Recuperado de https://doi.org/10.3738/1982.2278.3592

Souza, C. (2006, dezembro). Políticas Públicas: uma revisão da literatura. Sociologias, 8(16), 20-45. Recuperado de https://doi. org/10.1590/S1517-45222006000200003

Vianna, M. L. T. W. (1998). A americanização (perversa) da seguridade social no Brasil: estratégias de bem-estar e políticas públicas. Rio de Janeiro, RJ: Revan.

Weick, K. E. (2001). Making Sense of the Organization. Malden, MA: Blackwell.

Wu, X., Ramesh, M., Howlett, M., \& Fritzen, S. (2014). Guia de Políticas Públicas: gerenciando processos. Brasília, DF: ENAP.

Zahariadis, N. (1999). Ambiguity, Time, and Multiple Streams. In P. A. Sabatier (Ed.), Theories of the Policy Process. Denver, Colorado: Westview Press.

Zahariadis, N. (2007). The multiple streams framework: structure, limitations, prospects. In P. A. Sabatier (Ed.), Theories of policy process. Denver, Colorado: Westview Press.

Zahariadis, N. (2014). Ambiguity and Multiple Streams. In P. A. Sabatier, \& C. M. Boulder (Eds.), Theories of the Policy Process. Denver, Colorado: Westview Press.

Zanirato, S. H. (2003). O descanso do guerreiro: um estudo sobre a instituição da previdência social no Brasil. Maringá, PR: Eduem. 
Raquel Andrade Silva de Oliveira

ORCID: https://orcid.org/0000-0003-2611-7285

Mestra em Administração pelo Programa de Pós-Graduação em Administração (PPGAdm) da Universidade Federal de Viçosa (UFV). E-mail: raquel.a.andrade@ufv.br

\section{Bruno Tavares}

ORCID: https://orcid.org/0000-0002-5140-7359

Doutor em Administração pela Universidade Federal de Lavras (UFLA); Professor Associado do Departamento de Administração da Universidade Federal de Viçosa (UFV).E-mail: btavares@ufv.br

Thiago de Melo Teixeira da Costa

ORCID: https://orcid.org/0000-0002-0521-3799

Doutor em Economia Aplicada pela Universidade Federal de Viçosa (UFV); Professor associado do Departamento de Administração e Contabilidade da Universidade Federal de Viçosa (UFV). E-mail: thiagocosta@ufv.br

Suely de Fátima Ramos Silveira

ORCID: https://orcid.org/0000-0002-1303-7190

Doutora em Economia Aplicada pela Universidade de São Paulo (Esalq/USP); Professora do Programa de Pós-Graduação em Administração da Universidade Federal de Viçosa (UFV).E-mail: sramos@ufv.br 